\title{
Thermal Dynamic Behavior in Bi-Zone Habitable Cell with and without Phase Change Materials ${ }^{+}$
}

\author{
Hanae El Fakiri *, Lahoucine Ouhsaine and Abdelmajid El Bouardi \\ Energetic Laboratory, Thermal, Solar Energy and Environment Team (ETEE), Physics Department, Faculty of \\ Sciences, Abdelmalek Essaâdi University, Tetouan 93000, Morocco; ouhsaine.la@gmail.com (L.O.); \\ a_bouardi@yahoo.fr (A.E.B.) \\ * Correspondence: hanaefakiri@gmail.com; Tel.: +212-(0)671-53-80-04 \\ + Presented at the 14th International Conference on Interdisciplinarity in Engineering-INTER-ENG 2020, \\ Târgu Mureș, Romania, 8-9 October 2020.
}

Published: 21 December 2020

\begin{abstract}
The thermal dynamic behavior of buildings represents an important aspect of the energy efficiency and thermal comfort of the indoor environment. For this, phase change material (PCM) wallboards integrated into building envelopes play an important role in stabilizing the temperature of the human comfort condition. This article provides an assessment of the thermal behavior of a "bi-zone" building cell, which was built based on high-energy performance (HEP) standards and heated by a solar water heater system through a hydronic circuit. The current study is based on studying the dynamic thermal behavior, with and without implantation of PCMs on envelope structure, using a simplified modeling approach. The evolution of the average air temperature was first evaluated as a major indicator of thermal comfort. Then, an evaluation of the thermal behavior's dynamic profile was carried out in this study, which allowed for the determination of the PCM rate anticipation in the thermal comfort of the building cell.
\end{abstract}

Keywords: thermal comfort; phase change materials (PCMs); HEP building; thermal performance

\section{Introduction}

The sustained growth in the energy demand's dependence on fossil fuel and fluctuating prices, as well as environmental constraints, have prompted African countries to explore potential sources of energy savings. One of the promising responses is energy efficiency. In Morocco, since the launch of the national energy strategy in 2009, energy efficiency has become one of the main pillars for the sustainability and energy independence policy of the kingdom.

The building sector is among the most energy-demanding sectors in Morocco, with an energy consumption of up to $33 \%$ of the total energy in the country, including $26 \%$ for the residential sector and $7 \%$ for the tertiary sector. The building sector today has the greatest potential for improving energy efficiency by representing an energy-saving potential of $40 \%$ [1]. An important rate is dominated by heating, ventilation, and air conditioning (HVAC) systems. The Moroccan thermal standard was launched in 2015 to reduce the energy bill and environmental impact. Thus, highenergy performance (HEP) in building standards is a key element to achieve the Moroccan thermal regulation of buildings (RTCM) [2]. The thermal performances required in the RTCM differ according to the type of building (residential or tertiary) and according to the climatic zone by location [3].

Besides, several research works have been developed to improve building energy efficiency, the thermal performance of buildings, and energy consumption savings. In this context, several solutions have been presented, among them the incorporation of phase change materials (PCMs) as promising systems with the ability to improve the imbalance between energy supply and demand and provide high-energy storage density using latent heat.

Proceedings 2020, 63, 41; doi:10.3390/proceedings2020063041 
PCMs are substances that release or absorb energy during melting and freezing processes at a constant or semi-constant temperature based on the phase change temperature of the material.

Therefore, one of the uses of variable phase materials is the storage of latent thermal energy, whereby the variable phase materials combined with building materials can increase the thermal breakdown of buildings to contribute to reducing fluctuations in internal temperature and achieving internal thermal comfort, reducing the energy consumption needed for heating and air conditioning.

In the Mediterranean context, Mandilaras et al. [4] thermally characterize a typical two-story family house embedded with PCM gypsum pasteboard panels. They analyze the building walls orientation effect for meteorological conditions and with conducted experimental measurements, the authors conclude that the thermal mass enhancement for early summer and autumn results in a decrease in decrement factor by 30 to $40 \%$ and an increase in time lag by approximately $100 \mathrm{~min}$. These two cited factors are key output parameters to evaluate thermal performance inside buildings; they were also determined and discussed in the works of Kharbouch et al. [5] who investigated the thermal performance of PCM-enhanced walls and roofs in northern Moroccan buildings.

Most supplementary studies have also shown that PCM integration into building envelopes has major benefits. Mourid et al. [6,7] have been experimentally concluding that the application of PCMs on the envelope of a cavity living space is an effective technique for improving thermal comfort by storing heating losses, which reduces the electrical energy consumption, compared to a similar cavity without PCMs. Other research works [8,9] revealed experimentally that the optimal site to achieve greater efficiency by integrating PCMs was located closer to the interior surface of the wall. In addition, Li et al. [10] construed that building envelopes containing PMCs manifest different levels of enhancement by reducing peak temperature and temperature fluctuations. Li et al. [11] improved heat transfer reduction in multi-layer walls of conventional buildings by using PCMs.

This work aims to numerically investigate the thermal dynamic behavior of all the components of a whole building partially covered by PCMs and that of one without PCMs. The outcomes of the study may contribute to clearing the way for energy analysis and comparison with standard and conventional buildings in matters of thermal conditioning.

In the presented paper, the first part describes the thermal model and the proposed bi-zone building description, while the second part discusses briefly the developed scheme of numerical dynamic simulation as well as the different adopted scenarios that were shown to evaluate the use of PCMs in the building envelope. Finally, the results obtained from the dynamic simulation are developed to discover the optimal scenario in the proposed building.

\section{Thermal Model}

\subsection{Building Description}

The building studied is a prototype that was built at the Abdelmalek Essaadi University Faculty of Sciences in Tetouan (Figure 1), located in the climate Z2 zone [2], which is characterized by

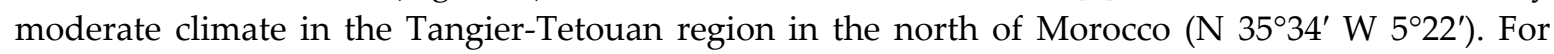
Moroccan conditions, the location is relatively rain-laden and is located on a plateau, about $90 \mathrm{~m}$ above mean sea level and $10 \mathrm{~km}$ south of the Mediterranean Sea. The city is surrounded by the Rif Mountains in the northern and southern directions. 

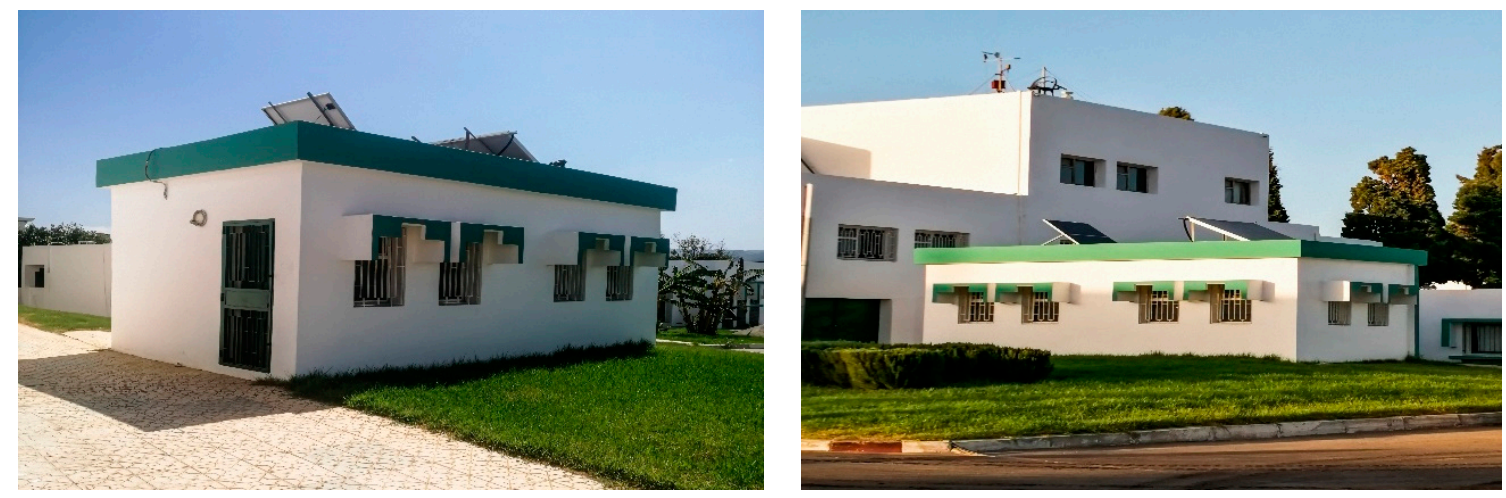

Figure 1. Perspective prototype of the bi-zone building.

The building has an entire area of $53 \mathrm{~m}^{2}$ and consists of two rooms, which are connected by a simple wooden door $(4 \mathrm{~cm}$ thick, $83 \mathrm{~cm} \times 210 \mathrm{~cm})$ as illustrated by Figure 2 . The entrance door on the north side of the building has a heat transfer coefficient of $1.627 \mathrm{~W} / \mathrm{m}^{2} \mathrm{~K}$; its structural characteristics are the same as those of the internal door. Furthermore, the building has six simple windows $(76 \mathrm{~cm}$ $\times 117 \mathrm{~cm}, 4 \mathrm{~mm}$ thick) with aluminum frames. Two are located in the south of the building, while four face westward. The thermo-physical characteristics of the building are summarized in Table 1.

In this work, the PCM wall board was proposed to be embedded in the inside part of the eastern and southern building faces, because those faces were assumed to receive the highest amount of daily solar radiation. Furthermore, this study intended to limit the integration of the PCM in the whole building for economic reasons and to investigate firstly the partial PCM integration in building walls (Figure 2).
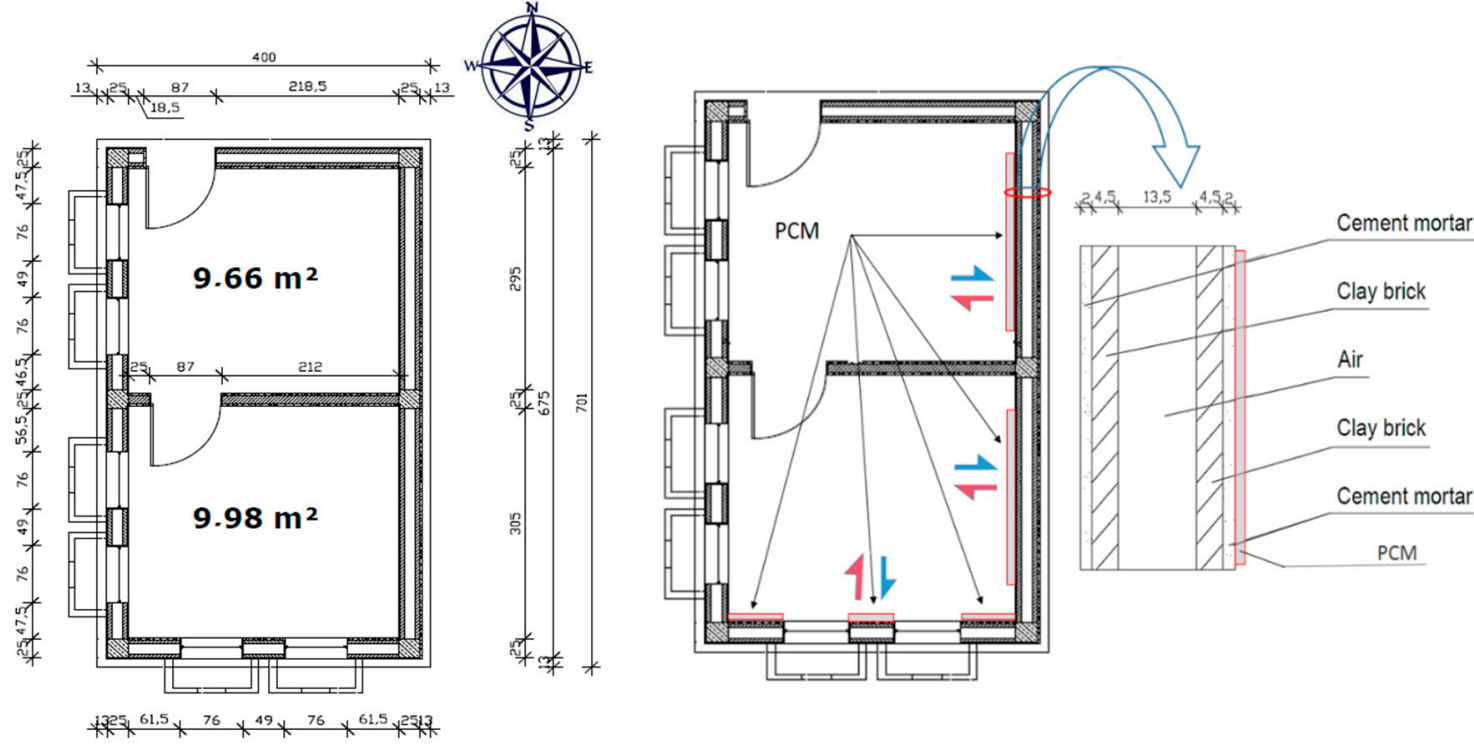

Figure 2. Bi-zone model prototype with and without phase change material (PCM) cases.

Table 1. Thermo-physical characteristics of the building.

\begin{tabular}{|c|c|c|c|c|c|c|}
\hline Components & $\begin{array}{c}\text { Sub- } \\
\text { Component }\end{array}$ & $\begin{array}{c}\text { Thickness } \\
\text { (mm) }\end{array}$ & $\begin{array}{l}\text { Thermal } \\
\text { Cond. } \\
\mathbf{W m}^{-1} \mathbf{K}^{-1}\end{array}$ & $\begin{array}{c}\text { Specific } \\
\text { Heat } \\
\text { Capacity } \\
\left(\mathrm{J} / \mathrm{kg}^{-1} \mathrm{~m}^{-3}\right)\end{array}$ & $\begin{array}{l}\text { Density } \\
\left(\mathrm{kg} / \mathrm{m}^{3}\right)\end{array}$ & $\begin{array}{l}\text { Heat Transfer } \\
\text { Coefficient U }\end{array}$ \\
\hline \multirow{5}{*}{ External wall } & Cement mortar & 2 & 0.42 & 1000 & 1800 & \multirow{5}{*}{$\begin{array}{l}\text { Heat transfer } \\
\text { coefficient: } \\
\mathrm{U}=1.43 \mathrm{~W} /\left(\mathrm{m}^{2}\right. \\
\mathrm{K})\end{array}$} \\
\hline & Clay brick & 4.5 & 0.34 & 1000 & 1784 & \\
\hline & Air (static) & 13.5 & 0.03 & 1000 & 1.29 & \\
\hline & Clay brick & 4.5 & 0.34 & 1000 & 1784 & \\
\hline & Cement mortar & 2 & 0.42 & 1000 & 1800 & \\
\hline
\end{tabular}




\begin{tabular}{|c|c|c|c|c|c|c|}
\hline \multirow{5}{*}{ Floor } & Gravel & 5 & 0.70 & 1000 & 1800 & \multirow{5}{*}{$\begin{array}{l}\text { Heat transfer } \\
\text { coefficient: } \\
\mathrm{U}=0.81 \mathrm{~W} /\left(\mathrm{m}^{2}\right. \\
\mathrm{K})\end{array}$} \\
\hline & $\begin{array}{l}\text { Reinforced } \\
\text { concrete }\end{array}$ & 35 & 1.65 & 880 & 2150 & \\
\hline & Cork & 4 & 0.05 & 1800 & 155 & \\
\hline & Screed & 5 & 1.0 & 1000 & 2000 & \\
\hline & Tile & 0.7 & 1.4 & 1000 & 2500 & \\
\hline \multirow[t]{2}{*}{ Entrances } & $\begin{array}{l}\text { Window: } \\
\text { single glazing } \\
\text { + frame }\end{array}$ & 4 & - & - & - & - \\
\hline & $\begin{array}{l}\text { Doors } \\
\text { wood } \\
\end{array}$ & 4 & - & - & - & $\begin{array}{c}\mathrm{U}=1.627 \mathrm{~W}\left(/ \mathrm{m}^{2}\right. \\
\mathrm{K})\end{array}$ \\
\hline \multirow{5}{*}{ Roof } & Tile & 0.7 & 1.4 & 1000 & 2500 & \multirow{5}{*}{$\begin{array}{l}\text { Heat transfer } \\
\text { coefficient: } \\
\mathrm{U}=1.43 \mathrm{~W} /\left(\mathrm{m}^{2}\right. \\
\mathrm{K})\end{array}$} \\
\hline & Cement mortar & 2 & 0.42 & 1000 & 1800 & \\
\hline & $\begin{array}{c}\text { Reinforced } \\
\text { concrete }\end{array}$ & 3.5 & 1.62 & 880 & 2150 & \\
\hline & $\begin{array}{l}\text { Hollow block } \\
\text { ceiling/toe } \\
\text { board }\end{array}$ & 15.5 & 0.60 & 880 & 1000 & \\
\hline & Cement mortar & 2 & 0.42 & 1000 & 1800 & \\
\hline
\end{tabular}

\subsection{Heat and Mass Transfer Modeling}

The chosen mathematical approach to model the thermal behavior in the bi-zone cell was the heat capacity and thermal conductivity variation concerning the PCM temperature method [12].

The heat equation in the solid-state is defined by the Laplace equation and reduced to the developed form described by the equation; this model describes formally the thermal balance in a transient regime without heat term sources for different sub-layers of the system in a wall sample.

$$
\rho_{i} C_{i} e_{i} \frac{d T_{i}}{d t}=\frac{k_{i}}{e_{i}}\left(T_{i-1}-T_{i}\right)-\frac{k_{i+1}}{e_{i+1}}\left(T_{i}-T_{i+1}\right) \quad \text { for } \quad i=1 \ldots . N
$$

where $\rho_{i}, C_{i}, k_{i}$, and $e_{i}$ are respectively the density, the heat capacity, the thermal conductivity, and the thickness of the layer $\mathrm{i}$, while $\mathrm{i}+1$ leads to the adjacent layer. It can be noted in this work that the reference for the indoor chosen direction is from indoor to outdoor. The integration of the PCM layer can be modeled by the following equation:

$$
\rho_{\phi} \mathrm{C}_{\phi}\left(\mathrm{T}_{\phi}\right) \mathrm{e}_{\phi} \frac{\mathrm{dT}_{\phi}}{\mathrm{dt}}=\frac{\mathrm{k}_{\phi}\left(\mathrm{T}_{\phi}\right)}{\mathrm{e}_{\phi}}\left(\mathrm{T}_{\phi-1}-\mathrm{T}_{\phi}\right)-\frac{\mathrm{k}_{\phi+1}}{\mathrm{e}_{\phi+1}}\left(\mathrm{~T}_{\phi}-\mathrm{T}_{\phi+1}\right)
$$

where $\phi$ subscript denotes the phase change material layer, while $\phi-1$ and $\phi+1$ corresponds to the adjacent layers in front (indoor air) and behind the PCM layer, respectively.

The approach used in this work consists to extend the wall model with and without PCM pasteboard into full-building bi-zone scale. Figure 3 represents the multi-scale process RC (resistance capacity) equivalent network modeling for a 1D single wall to a mono and then for a full bi-zone dynamic model with and without PCMs. The heat capacity and thermal conductivity variation were developed in the work of Kharbouch et al. [5]; the PCM used in this work was composed of paraffinwax microcapsule material and its phase change temperature was $21^{\circ} \mathrm{C}$, which is near thermal comfort conditions.

The heat transfer between the building envelopes and its outdoor and indoor environments is realized by convection and radiation. The thermo-physical parameters are estimated by referring to the literature and physical assumptions. Figure 4 represents 38 thermal points' predictions that are determined by the simplified dynamic model in the case of PCM integration. 

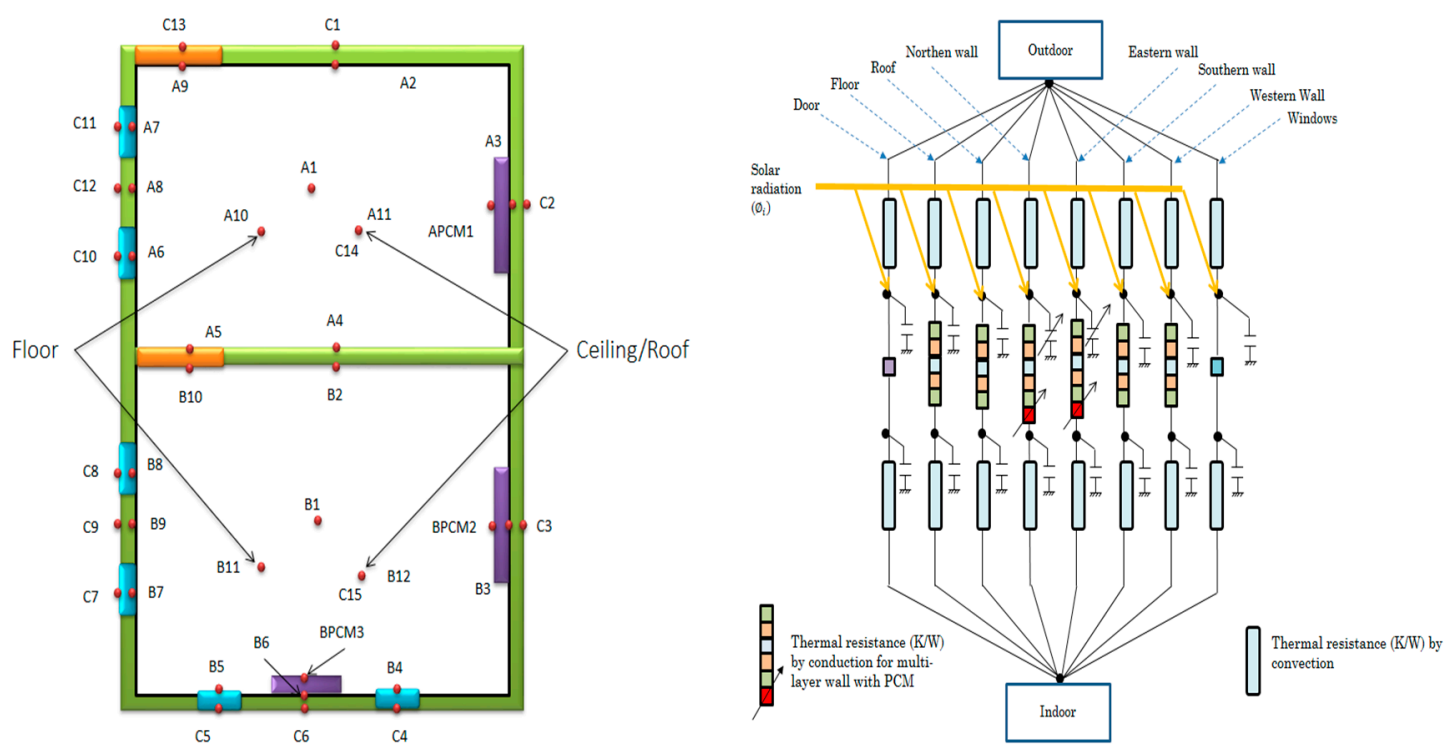

Figure 3. The multi-scale process RC equivalent network modeling.

\section{Dynamic Simulation}

\subsection{Meteorological Data (Hourly TMY)}

The meteorological data used were extracted from the hourly typical meteorological years) (TMY) Meteonorm database where different levels of global solar radiation that rose into the four facades (north, south, east, and west) were checked. Additionally, the ambient temperature and the wind speed were also useful in this work [13].

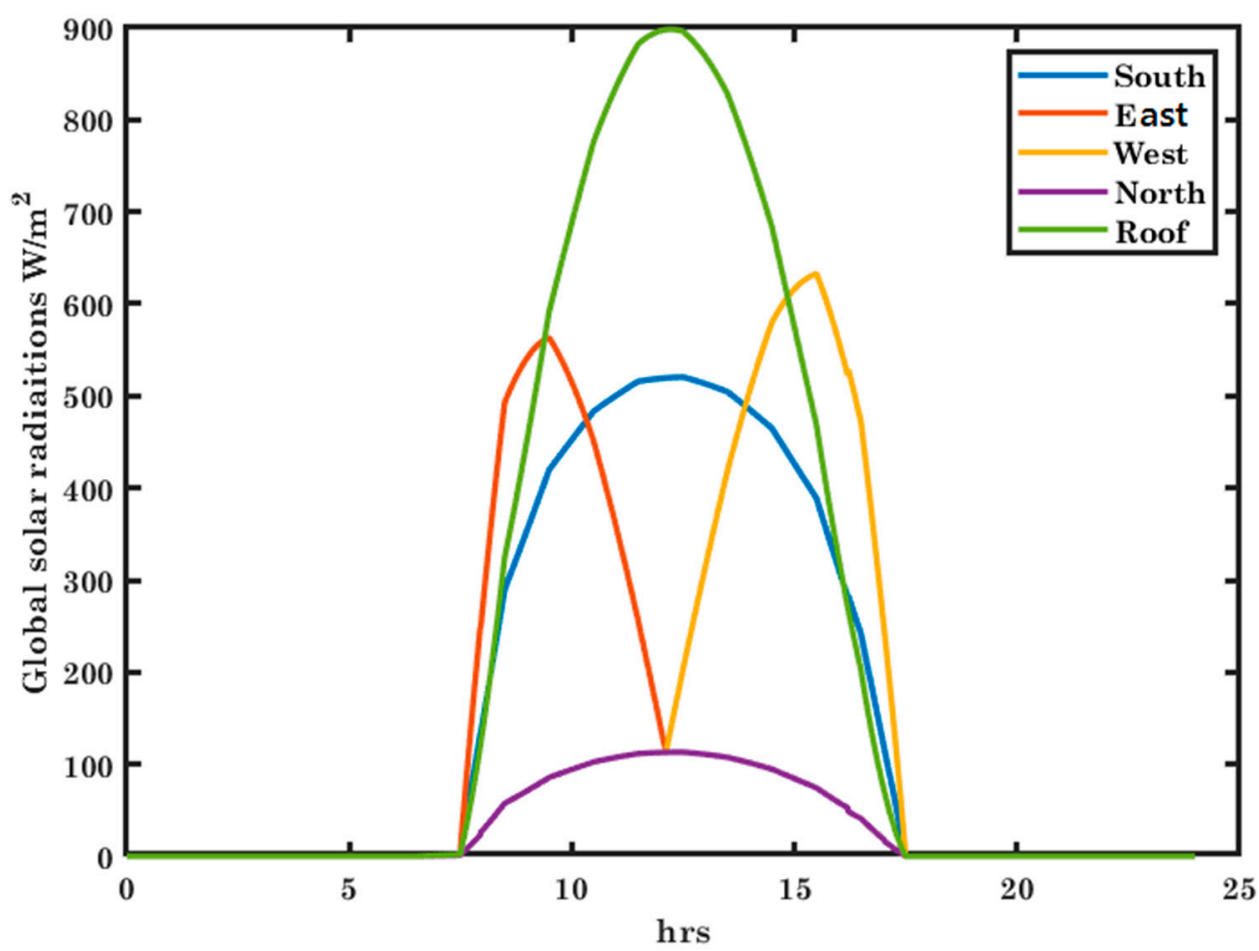

Figure 4. Solar radiation density issued in different surfaces for the first day in January.

\subsection{Finite Difference Method}

The finite difference method (FDM) is one of the performing numerical simulation methods that were employed to resolve differential equations, by substituting the derivatives in the equation using 
differential quotients, principally approximating the boundary conditions value problems by appropriate finite-difference operators [14]. FDM consists of approximating the derivatives of the heat equation-employing Taylor expansions and is deducted directly from the definition of the derivative [15].

The governing equation was solved along with the corresponding boundary and initial conditions using a finite difference method. The simulations were performed using MATLAB Software. The thermal transfer and storage processes of PCMs were taken into account by employing a one-dimensional conduction finite-difference solution as the heat balance algorithm. To account for phase change energy, this algorithm gives an implicit finite difference scheme combined with heat capacity and thermal conductivity function.

\section{Results and Discussion}

Dynamic simulation was conducted to determine the thermal behavior in the unheated bi-zone habitable cell with and without phase change materials (PCMs). It is worthwhile to know that the modeling approach predicted the temperature dynamics state for about 41 components of the system with PCMs and 38 components for the non-PCM case.

\subsection{Thermal Profile in Winter Day}

Figure 5 represents the temperature dynamic behavior with PCM integration phase for the 10th to the 12th day of January 2012. It can be seen that the PCMs amplify the natural heat sources in the indoor area. The southern side of the building that is most exposed to the sun causes high thermal behavior in indoor surfaces.

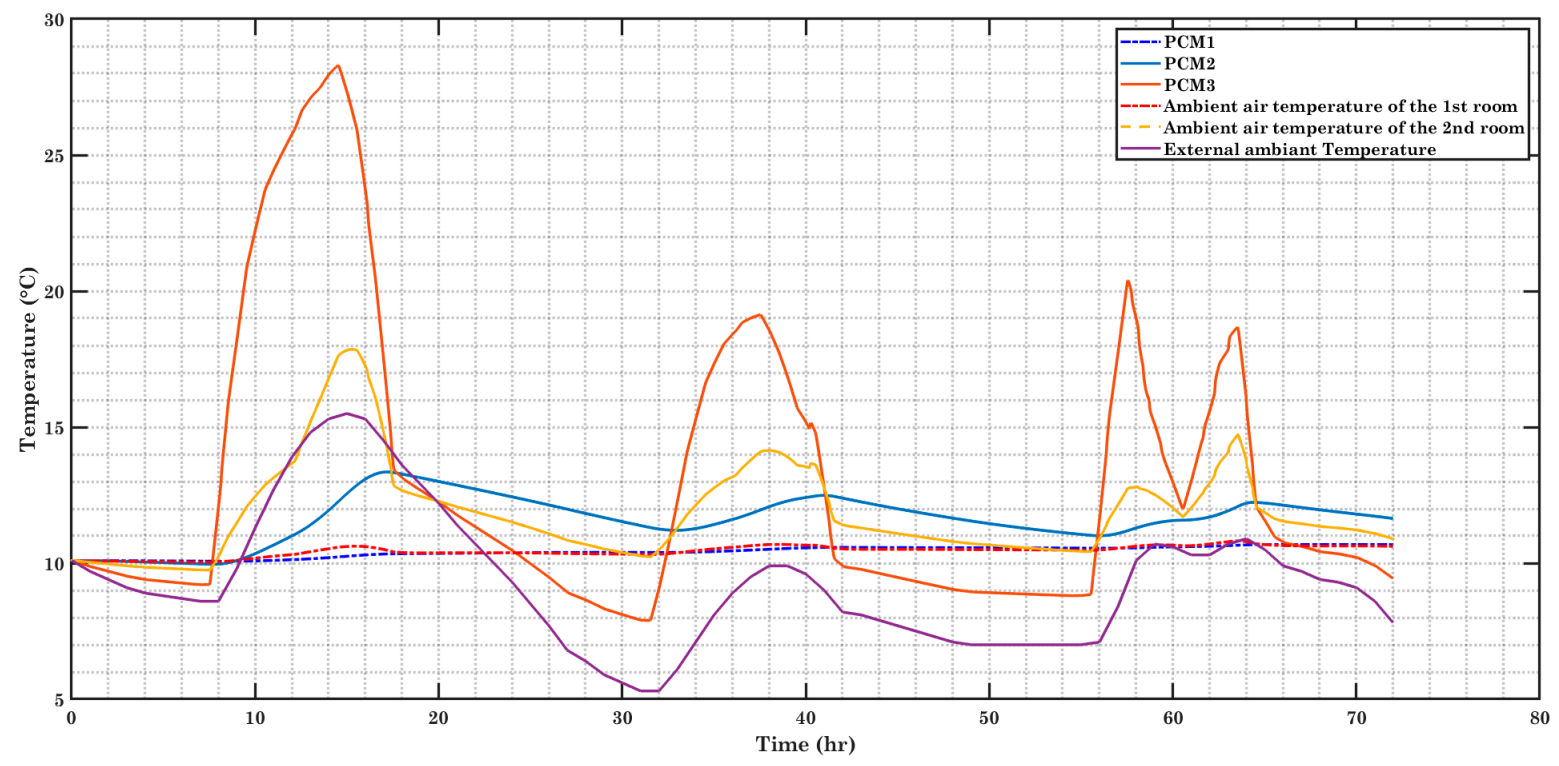

Figure 5. Time evolution of the temperatures of the cells without PCMs.

Figure 6 represents the temperature dynamic behavior without the PCM integration cases, and it can be seen that the temperature profile is lower than the temperature profile of the PCM case integration. 


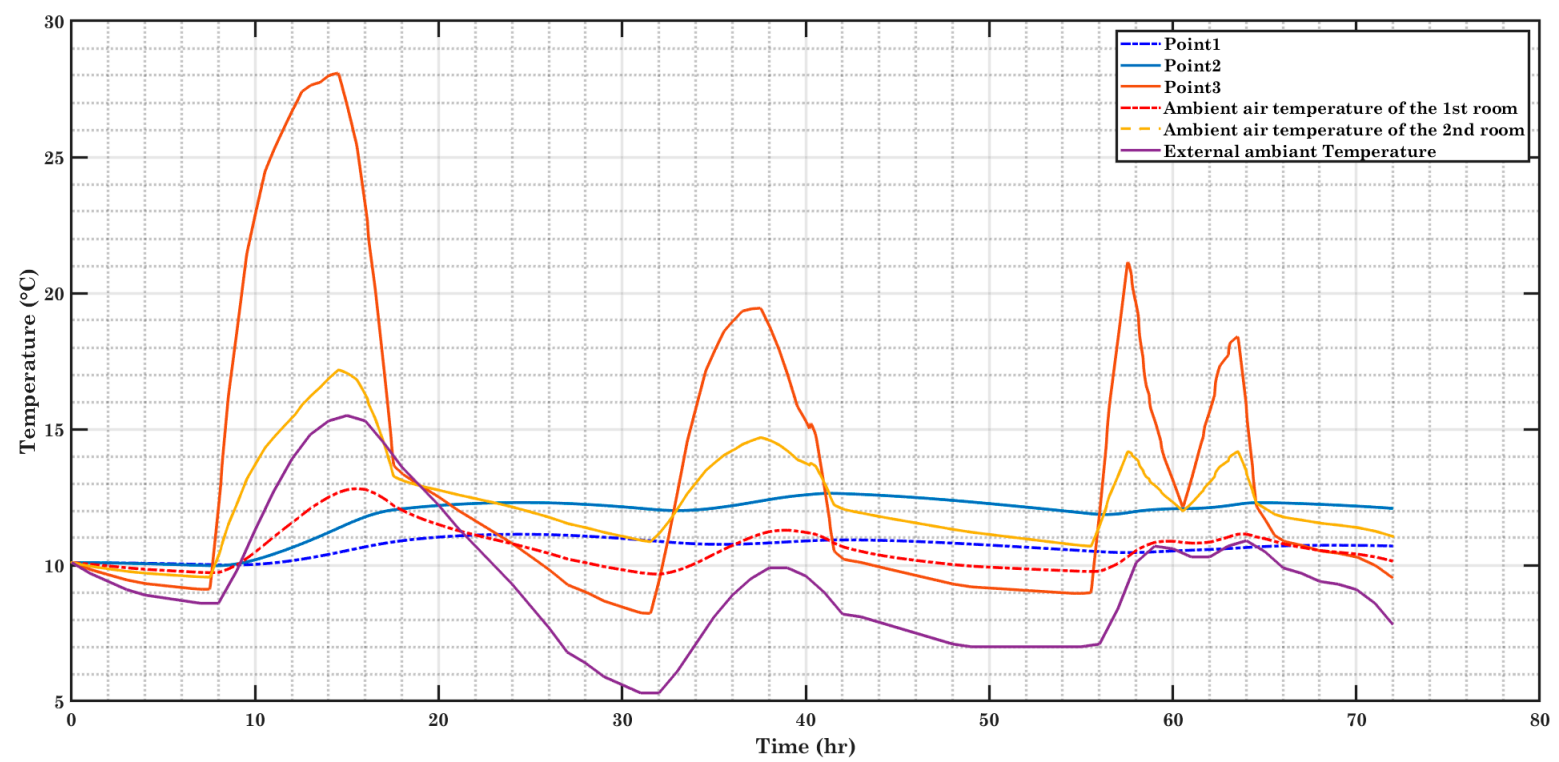

Figure 6. Time evolution of the temperatures of the cells with PCMs.

\subsection{Thermal Profile in Summer Period}

In this section, we show temporal evolutions of the temperature for the cells with and without PCMs. During the trees first day of July in the summer period, it can be seen from Figures 7 and 8 that the PCMs reduce significantly the thermal behavior in the building cells for the first room and has negative impact for the second room in the summer period.

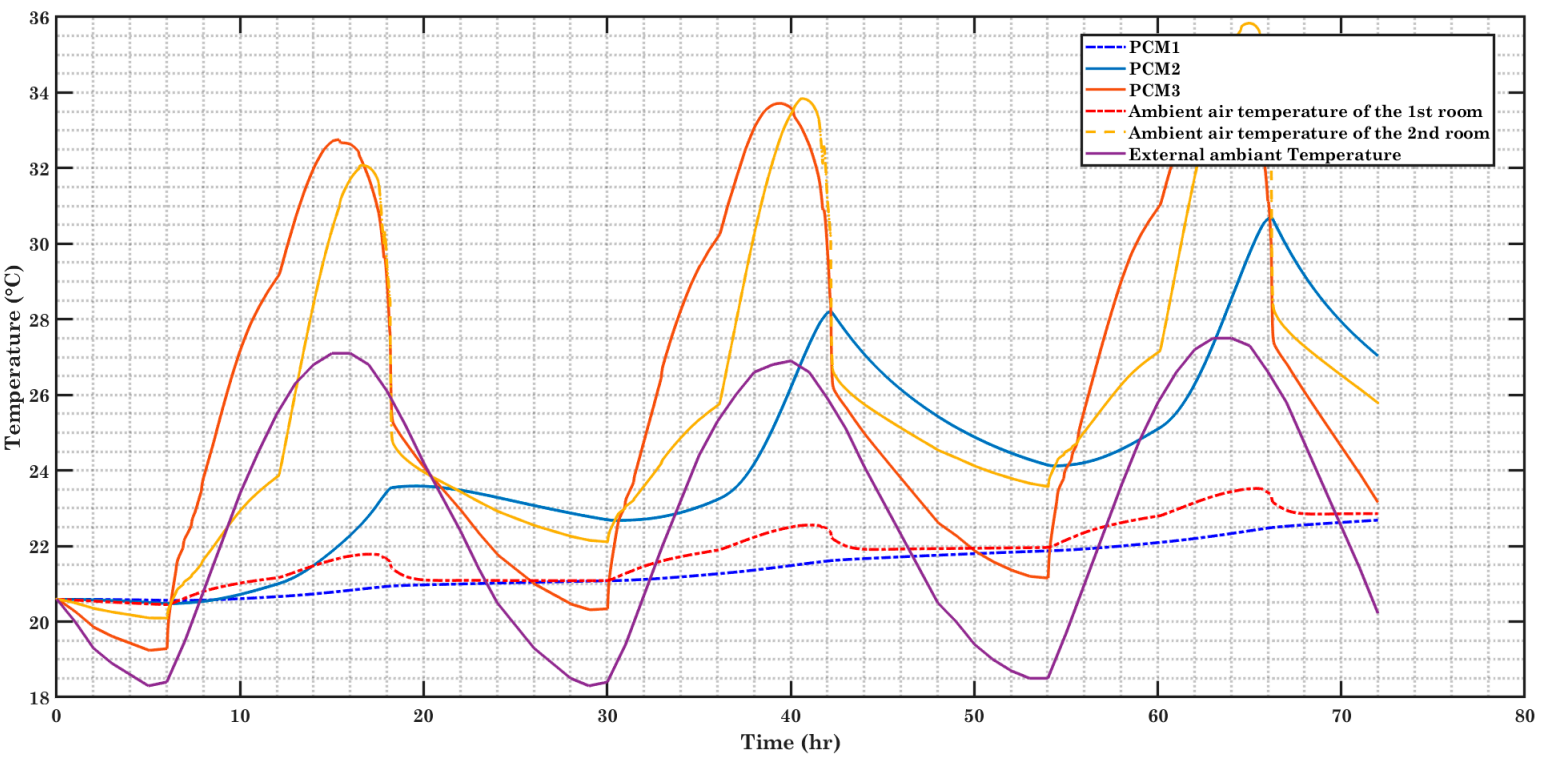

Figure 7. Time evolution of the temperatures of the cells without PCMs. 


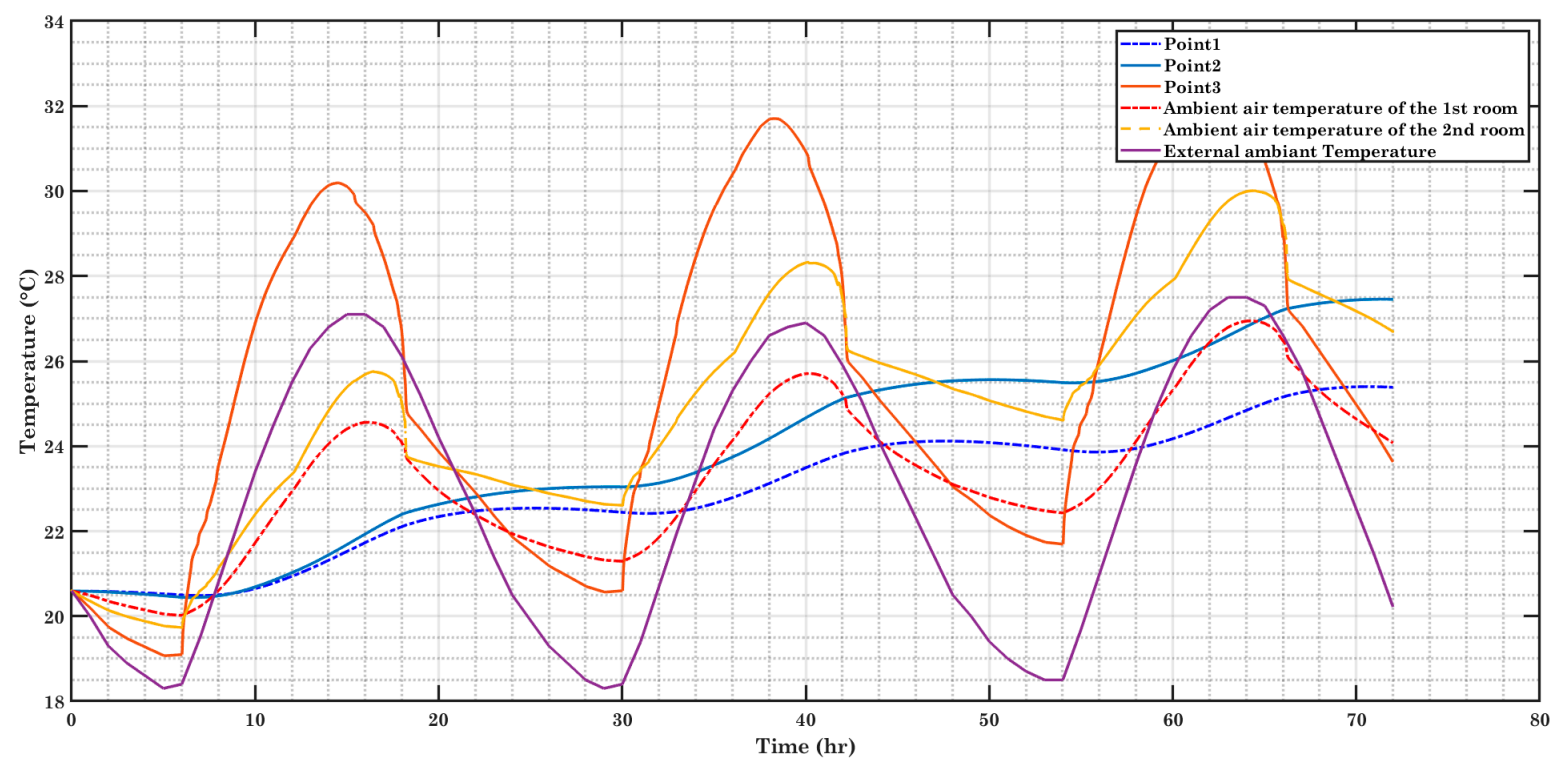

Figure 8. Time evolution of the temperatures of the cells with PCMs.

\section{Conclusions}

The aim of this study was to investigate the thermal behavior of PCM integration in a bi-zone building cells. The dynamic simulation was conducted for 31 subcomponents. The represented results show the dynamic thermal profile along the daytime period. The study was limited to the dynamic simulation and the comparison with the partial PCM integrations into the indoor walls. The prospect of this study was to investigate deeply the effect of the parameters that control the mathematical model, and to optimize the PCM integration in the buildings.

Author Contributions: Conceptualization, methodology, validation, original draft preparation, review, and editing by H.E.F. and L.O.; supervision by A.E.B. All authors have read and agreed to the published version of the manuscript.

Conflicts of Interest: The authors declare no conflict of interest.

\section{References}

1. AMEE. Moroccan Agency for Energy Efficiency: Energy efficiency in buildings. Available online: https://www.amee.ma/en/node/118 (accessed on 10 June 2020).

2. AMEE. Moroccan Agency for Energy Efficiency: La Règlementation thermique dans le bâtiment (RTCM). Available online: https://www.amee.ma/reglementation-thermique (accessed on 10 June 2020).

3. AMEE. Construction Building Thermal Regulation Code in Morroco (TRCM), Zonage Climatique du Maroc Adapté au Règlement Thermique de Construction au Maroc; AMEE: Dundee, Finland, 2018.

4. Mandilaras, I.; Stamatiadou, M.; Katsourinis, D.; Zannis, G.; Founti, M. Experimental thermal characterization of a Mediterranean residential building with PCM gypsum board walls. Build. Environ. 2013, 61, 93-103, doi:10.1016/j.buildenv.2012.12.007.

5. Kharbouch, Y.; Ouhsaine, L.; Mimet, A.; El Ganaoui, M. Thermal performance investigation of a PCMenhanced wall/roof in northern Morocco, Build. Simul. 2018, 11, 1083-1093, doi:10.1007/s12273-018-0449-5.

6. Mourid, A.; Alami, M.E. Experimental analysis of the thermal behavior of two cavities kind of living space with and without PCM on envelopes. Int. J. Mod. Embed. Syst. 2017, 5, 7.

7. Mourid, A.; Alami, M.; Kuznik, F. Experimental investigation on thermal behavior and reduction of energy consumption in a real scale building by using phase change materials on its envelope. Sustain. Cities Soc. 2018, 41, 35-43, doi:10.1016/j.scs.2018.04.031.

8. Jin, X.; Hu, H.; Shi, X.; Zhou, X.; Yang, L.; Yin, Y.; Zhang, X. An improved heat transfer model for building phase change material wallboard. J. Therm. Anal. Calorim. 2018, 134, 1757-1763, doi:10.1007/s10973-018$7357-x$ 
9. Li, M.; Gui, G.; Lin, Z.; Jiang, L.; Pan, H.; Wang, X. Numerical Thermal Characterization and Performance Metrics of Building Envelopes Containing Phase Change Materials for Energy-Efficient Buildings. Sustainability 2018, 10, 2657, doi:10.3390/su10082657.

10. Arıc1, M.; Bilgin, F.; Nižetić, S.; Karabay, H. PCM integrated to external building walls: An optimization study on maximum activation of latent heat. Appl. Therm. Eng. 2020, 165, 114560, doi:10.1016/j.applthermaleng.2019.114560.

11. Li, Z.X.; Al-Rashed, A.A.; Rostamzadeh, M.; Kalbasi, R.; Shahsavar, A.; Afrand, M. Heat transfer reduction in buildings by embedding phase change material in multi-layer walls: Effects of repositioning, thermophysical properties and thickness of PCM. Energy Convers. Manag. 2019, 195, 43-56, doi:10.1016/j.enconman.2019.04.075.

12. Meteonorm Software Worldwide Irradiation Data, Weather Stations and Satellites, NREL TMY Dataset Downloads. Available online: http://www.meteonorm.com/en/ (accessed on 13 July 2020).

13. Akeiber, H.; Nejat, P.; Majid, M.Z.; Wahid, M.A.; Jomehzadeh, F.; Famileh, I.Z.; Calautit, J.K.; Hughes, B.R.; Zaki, S.A. A review on phase change material (PCM) for sustainable passive cooling in building envelopes. Renew. Sustain. Energy Rev. 2016, 60, 1470-1497, doi:10.1016/j.rser.2016.03.036.

14. Kośny, J. Short History of PCM Applications in Building Envelopes. In PCM-Enhanced Building Components; Springer: New York, NY, USA, 2015; pp. 21-59.

15. Voller, V.R. Fast implicit finite-difference method for the analysis of phase change problems. Numer. Heat Transf. Part B Fundam. 1990, 17, 155-169, doi:10.1080/10407799008961737.

Publisher's Note: MDPI stays neutral with regard to jurisdictional claims in published maps and institutional affiliations.

(C) 2020 by the authors. Submitted for possible open access publication under the terms and conditions of the Creative Commons Attribution (CC BY) license (http://creativecommons.org/licenses/by/4.0/). 